\title{
EXTRATERESTRICKÉ BAZALTY NWA 5235 A HaH 286 A JEJICH POROVNÁNÍ S MORAVSKÝM METEORITEM STONAŘOV
}

\author{
Extraterrestrial basalts NWA 5235 and $\mathrm{HaH} 286$ and comparison with Moravian meteorite \\ Stannern
}

\author{
Magdalena Šimčíková \\ Ústav petrologie a strukturní geologie, Prírodovědecká fakulta Univerzity Karlovy v Praze, Albertov 6, 12843 Praha 2; \\ e-mail:magdalena.simca@seznam.cz
}

Key words: Stonařov, asteroide Vesta, Stannern trend eucrites, pyroxenes

(23-41 Třešt')

\begin{abstract}
Moravian meteorite Stannern is the only one meteorite fallen into our region which represents achondrite group of meteorites. This meteorite is very unique due to its composition and it is one of the most examined meteorite - eucrite in the world. Samples of eucrites NWA 5235 and HaH 286 found in african deserts were studied and compared with Stannern trend eucrites. NWA 5235 is relatively fresh, HaH 286 is weakly weathered, with fractures filled by calcite. Electron microprobe analyses showed that these meteorites represent typical non cumulate basalts which fall within main trend eucrites. They mainly consist of pyroxenes (low-Ca pyroxenes and augites) and plagioclase (bytownite - anorthite). Accessories include ilmenite, chromite, rarely silica phase, troilite and metal Fe. The bulk composition of these samples has been determined for major elements. Research of these meteorites helps to understand the petrological context of their parent bodies. It also leads to understanding of magmatic processes of asteroid 4 Vesta which is believeded to be the parent body of the eucrites.
\end{abstract}

\section{Úvod}

Výzkum extraterestrického bazaltického vulkanismu je velmi efektivním způsobem získávání informací o vývoji těles Sluneční soustavy. Fyzické vzorky pro př́imý výzkum mohou být získány nákladným transportem z mimozemských těles nebo na Zemi náhodně zavítají samy jako meteority. Dle úrovně současného poznání se nalézají v pozemských sbírkách desítky meteoritů z Měsíce a Marsu a desítky tisíc asteroidálních meteoritů, nalézaných ponejvíce v Antarktidě a afrických pouštích. Meteorit Stonařov (zvaný mezinárodně dle německého názvu obce Stonařov „Stannern“) byl od počátku v popředí vědeckého zájmu. Představuje zatím jediný nález achondritu u nás. Dopadl na Moravě 22. května 1808 jako déšt meteoritů o 200-300 kusech, jež dosahovaly hmotnosti několika gramů až kg. O tom, že šlo i tehdy o významnou událost, se můžeme dočíst např. $v$ dobovém tisku Kraméryusovy cýs. král. Wlastenecké Nowiny, Nro. 26, 25. června 1808:

\section{Na Moravě kamení s nebe pršelo Hromové rány $v$ neproniknutelné mlze}

„Z Moravy 15. června. Dne 22. minulého měsíce mezi pátou a šestou hodinou ráno se stal $v$ Štanrích a okolo Štaner nedaleko Jihlavy zvláštní prirozený př́běh v povětří.. $V 6$ hodin vyvstala mlha, že se nemohlo za malou chvíli žádné věci rozeznati. Obyvatelé z okolních míst šli právě do Štaner do kostela, když udeřilo třikrát prudce, hromu podobně, po čemž udeřilo ještě víckrát, ale slaběji, což zděsilo všecky lidi. Když se to dálo, padalo u Štanern, Mittelsdorfu, Dyru, dlouhé Pirmice, Otnu a Falkenova kamení jako vlaští oŕechové i jako dětská hlava, a těžké $1 / 2$ lotu až do 3 liber, z povětrí. Mnozí lidé je vidéli padati a víc lidí je $z d v i h l o, k d y z ̌$ padlo, a shledalo, že je ještě teplé. Na pohled je to kamení jako měsínné neb meteorské kamení; když se roztluče, je písčivé a šeré a má černou, blýskavou kưru. Bylo ho asi 200 kusů... Když se to oznámilo, nařídil jeho cýs. král. Milost dyrektoru panu Karlovi ze Schreibrů..., aby tam dojel a toho príběhu uměle a dokonale vyšetřil a popsal jej, což se i stalo. Kamení, které sebral, váží as 25 liber... " (převzato z Kohlík 1970). Celkový přehled historických zápisů a zmínek o pádu stonařovského meteoritu shrnuje Peltán (2008) a souhrn výsledků petrologických a chemických analýz uvádí Šimčíková (2008) u přiležitosti dvoustého výročí pádu meteoritu Stannern.

V době pádu tohoto meteoritu byly známy jen dva typy meteoritů - železné a kamenné chondrity. Schreibers $(1808,1809)$ určil stonařovské kameny jako nový typ meteoritů - vulkanické brekcie. Poté byly tyto meteority zkoumány vídeňským petrografem Tschermakem (např. 1872). V klasifikaci Roseho (1863) byl již pro klasifikaci meteoritu Stannern použit termín eukrit - z řeckého „eukritos“, $\mathrm{tj}$. snadno rozpoznatelný (míněno pro jeho součásti živce a pyroxeny). Eukrity jsou patrně fragmenty kůry asteroidu - dle analýz se jedná o větší těleso - asteroid 4 Vesta (např. Consolmagno - Drake 1977, Drake 1979, Melosh 1984). Stejný původ má i další typ meteoritů - tzv. diogenity (hořečnaté ortopyroxenity), které představují patrně plášt tohoto tělesa. Howardity jsou směsí eukritového a diogenitového materiálu a jejich brekcií, což naznačuje společný původ z jednoho mateřského tělesa, stejně jako zjištění charakteru izotopů kyslíku (Clayton - Mayeda 1996). Howardity spolu s eukrity a diogenity tvoří skupinu tzv. HED achondritů. Stannern se díky svým odlišnostem stal typovým meteoritem pro samostatnou a vzácnou skupinu achondritů (Stannern trend) a vzorky tohoto meteoritu jsou uloženy ve sbírkách nejméně 124 muzeí a odborných světových institucí (Ondra 2008, Köblitz 1994). Obecně přijímaná klasifikace meteoritů HED je uvedena v tab. 1. Eukrity představují jedny z nejstarších meteoritů (dle četných, obecně udávaných radiometric- 


\begin{tabular}{|l|}
\hline Klasifikace a charakteristika achondritů HED \\
\hline Diogenity - monomiktní nebo nebrekciovité achondrity s ortopyroxeny a olivíny \\
\hline Eukrity - pyroxen-plagioklasové achondrity \\
nekumulátní eukrity \\
hlavní skupina, typ Juvinas - pyroxeny bez zonálnosti, s odmíšenými lamelami dle (001) \\
typ Stannern/Nuevo Laredo \\
typ Pasamonte - povrchový, lávový typ (zonální pyroxeny bez odmíšených lamel) \\
kumulátní eukrity \\
typ Binda - Ca pyroxen s odmíšenými lamelami dle (100) \\
typ Moore County - pigeonit je částečné přeměněn na ortopyroxen \\
polymiktní eukrity - polymiktní brekcie diogenitů a eukritů, podíl ortopyroxenů < $10 \%$ \\
\hline Howardity - polymiktní brekcie z diogenitů a eukritů, podíl ortopyroxenů > 10\%
\end{tabular}

Tab. 1. Klasifikace achondritů HED (upraveno dle Takedy 1997). Tab. 1. HED achondrite classification (after Takeda 1997).

kých dat 4,54+/-0,02 Ga). Většina z nich jsou monomiktní brekcie, nebrekciované bazalty se vyskytují vzácněji. Jedná se o horniny tvořené převážně cca $60 \%$ pyroxenu a cca $35 \%$ Ca-plagioklasu, bez př́tomnosti hydratovaných fází. Eukritové bazalty jsou poměrně bohaté na Fe, což vykazují i jejich pyroxeny (Takeda - Graham 1991). Obsahy Fe a Mn v pyroxenech eukritů se liší od pozemských i měsíčních pyroxenů (Papike et al. 1998). Primárním pyroxenem je Fe-pigeonit s častými exsolučními lamelami ferroaugitu. Plagioklasy mají složení bytownit - anortit, s nízkými obsahy $\mathrm{K}_{2} \mathrm{O}(0,2-0,3 \mathrm{hm}$. \%), u eukritů Stonařov a Nuevo Laredo byly zjištěny obsahy vyšší. V kumulátových eukritech (hrubozrnná gabra) má plagioklas zvýšený podíl Ca-komponenty na rozdíl od plagioklasů bazaltických eukritů. Částečně kumulátové eukrity obsahují krystalové kumuláty a podstatný podíl utuhlé taveniny.

\section{Mineralogie, petrologie a stáří eukritů typu Stannern}

Moderní petrologickou charakteristiku meteoritu Stannern provedl Engelhardt (1963), který rozlišil jeho dvě odlišné struktury - ofitickou a brekciovitou. Chemismus pak kompletně studovali Kitts - Lodders (1998) s výsledným zařazením eukritu Stannern mezi brekciovité monomiktní nekumulátní eukrity. Hlavní minerální složení eukritu Stannern sestává dle těchto autorů z pyroxenu $\mathrm{En}_{35} \mathrm{Fs}_{48} \mathrm{Ws}_{15} \mathrm{Rh}_{2}$ a živce $\mathrm{An}_{85} \mathrm{Ab}_{14} \mathrm{Or}_{1}$, vypočítaná hustota celé horniny činí $3,2 \mathrm{~g} / \mathrm{cm}^{3}$. Podle Irelanda a Bukovanské (1992), Bukovanské et al. (1998) a Bukovanské (2008) má ortopyroxen složení $\mathrm{En}_{35} \mathrm{Fs}_{63} \mathrm{Wo}_{2}$, pigeonit En $\mathrm{Es}_{31} \mathrm{Fs}_{57}$ $\mathrm{Wo}_{12}$ a klinopyroxen $\mathrm{En}_{31} \mathrm{Fs}_{41} \mathrm{Wo}_{28}$. Dalšími minerály jsou tridymit, chromit (bohatý ulvöspinelovou složkou), ilmenit, zirkon, slitina NiFe, troilit a whittlockit. Podle obsahů a poměrů izotopů $\mathrm{U}$ a $\mathrm{Pb}$ ve vzácně se vyskytujících zirkonech bylo těmito autory iontovou mikrosondou SHRIMP určeno stáří meteoritu Stannern na 4550 + 10 Ma. V hornině byl detekován cca $4 \%$ podíl částečně nataveného materiálu (Consolmagno - Drake 1977). Živce mají oproti ostatním eukritům větší množství draselné složky (Birck - Allegre 1978). Newson - Drake (1982) charakterizovali Stannern jako frakcionovaný eukrit, odvozený od materiálu asteroidu s velmi nízkým obsahem kovů. Na základě těchto odlišností od ostatních eukritů (Ikeda - Takeda 1985) byly další podobné meteority zařazeny do eukritů typu Stannern.

\section{Vznik eukritů}

Nejstarší model vzniku eukritů podal Mason (1962): nejprve došlo k úplnému roztavení původního tělesa chondritového složení ochuzeného o $\mathrm{Na}$ a následně $\mathrm{k}$ segregaci kovového jádra. Ve vzniklé silikátové tavenině proběhla frakční krystalizace a eukrity byly zřejmě součástí rezidua. Kůra mateřského tělesa tak byla tvořena eukrity, v hlubší části tělesa se tvořily howardity a diogenity. Podle modelu Stolpera (1977) vznikají eukrity jako produkty parciálního tavení pláště primitivního asteroidu, jehož složení odpovídalo průměrnému složení sluneční soustavy. Díky objevení možného tepelného zdroje ${ }^{26} \mathrm{Al}$ (Gray et al. 1973) se moderní názory na vznik eukritů přiklánějí k modelu Masona (1962), který považoval eukrity za produkt krystalizace magmatu - na rozdíl od modelů, upřednostňujících vznik eukritů parciálním tavením pevného pláště (např. Stolper 1977, Consolmagno - Drake 1977). K termálním procesům, pozorovaným na eukritech, docházelo zřejmě během vnitřní metamorfózy tělesa způsobené rozpadem nuklidů s krátkou životností $\left({ }^{26} \mathrm{Al}\right)$ a během impaktů.

\section{Vznik eukritů typu Stannern, hlavní skupiny eukritů a eukritů trendu Nuevo Laredo}

Výsledky práce Barrata et al. (2007) nasvědčují, že eukrity typu Stannern vznikly kontaminací materiálu hlavní skupiny eukritů (typ Juvinas) taveninou, vzniklou parciálním tavením kůry mateřského tělesa (obr. 1). Tomu odpovídají i koncentrace inkompatibilních prvků s Eu, Sr, Be anomáliemi, popř. neobvyklé vesikulární textury jako důsledek opětovného zahřátí během mohutného impaktu (Barrat et al. 2007). Yamaguchi et al. (2009) popsali novou

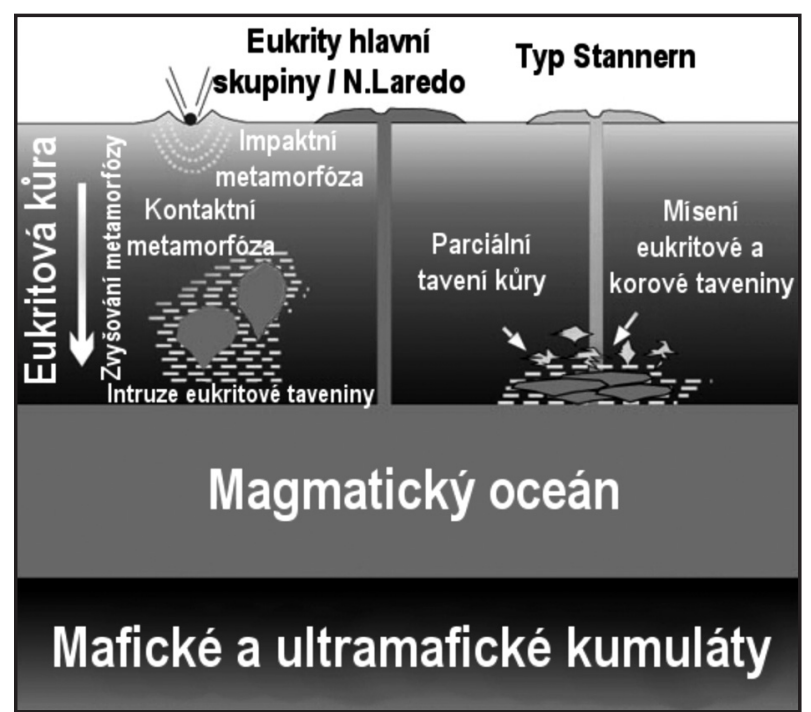

Obr. 1: Model vzniku eukritů typu Stannern a hlavní skupiny/ Nuevo Laredo (Barrat et al. 2007).

Fig. 1: Model of the origin of the Stannern and main group/Nuevo Laredo eucrites (Barrat et al. 2007). 
kategorii, tzv. „reziduální eukrity“, které jsou restitem (tzn. zbytkovou, neroztavenou horninou) po ztrátě taveniny, jež následně kontaminovala kůru o složení hlavní eukritové skupiny - typ Nuevo Laredo za vzniku Stannern typových eukritů. Petrologií eukritů typu „Stannern“ se dále zabývali Gardner - Mittlefehldt (2004) s navržením dvou krystalizačních fází pyroxenu - během magmatismu a následně při erupci.

\section{Asteroid 4 Vesta}

Jedním $\mathrm{z}$ nejvíce sledovaných asteroidů $\mathrm{v}$ současnosti je 4 Vesta, který byl v období červenec 2011 až září 2012 zkoumán sondou Dawn (NASA). Asteroid Vesta je již na základě spektrálních měření delší dobu považován za mateřské těleso HED achondritů (např. Consolmagno - Drake 1977, Drake 1979). Má tvar rotačního elipsoidu o průměru cca $530 \mathrm{~km}$ a je třetím největším asteroidem, objeveným v roce 1807 lékařem $\mathrm{H}$. W. Olbersem a pojmenovaným po římské bohyni Vestě - ochránkyní domácího krbu. Ve středu tělesa $\mathrm{s}$ předpokládanou hustotou asi $3,5 \mathrm{~g} / \mathrm{cm}^{3}$ působí tlak $1 \mathrm{~kb}$. Vesta je ojedinělým zástupcem spektrální třídy $\mathrm{V}$ hlavního pásu asteroidů, obíhajících mezi Marsem a Jupiterem. První moderní spektrometrické údaje, získané McCordem et al. (1970), detekovaly přítomnost $\mathrm{Fe}^{2+}$ (v pozici M2 u Mg-pyroxenu), čímž se Vesta lišila od dalších velkých asteroidů Ceres a Pallas. Nejpodobnější spektra vykazovaly bazaltické achondrity, konkrétně eukrit Nuevo Laredo. Spektrální měření Vesty v infračerveném spektru (Larson - Fink 1975) zjistila př́ítomnost pigeonitického pyroxenu, identického s pyroxeny eukritů, čímž se potvrdila souvislost Vesty s eukrity. Obrovský impaktní kráter na jižní polokouli je považován za možný zdroj HED meteoritů (Thomas et al. 1997). Nejnovější výsledky mise Dawn nám asteroid Vestu představují jako těleso s výraz-

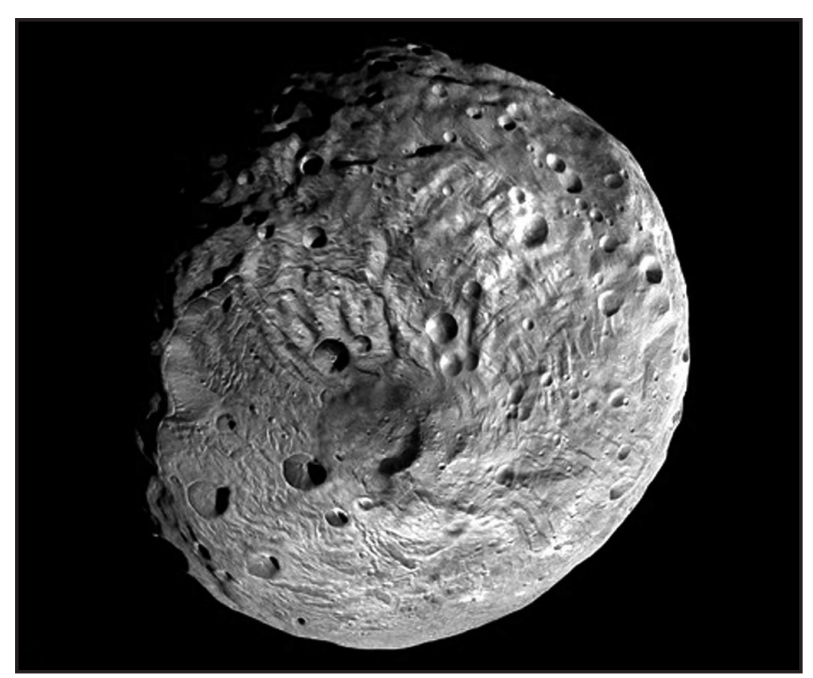

Obr. 2: Fotografie asteroidu Vesta v oblasti jižního pólu, pořízen ze vzdálenosti cca $2700 \mathrm{~km}$, rozlišení cca $260 \mathrm{~m} /$ pixel (sonda Dawn, NASA). Image credit: NASA/JPL-Caltech/UCLA/MPS/ DLR/IDA (http://www.nasa.gov/dawn).

Fig. 2: The south pole of the giant asteroid Vesta (framing camera on NASA's Dawn spacecraft) - the image was recorded from a distance of about 2,700 kilometres, resolution is about 260 metres per pixel. Image credit: NASA/JPL-Caltech/UCLA/MPS/DLR/ IDA (http://www.nasa.gov/dawn). ným povrchovým reliéfem (útesy, planiny, rovníkové žlaby, impaktní krátery). Bylo zde také objeveno jedno z nejvyšších pohoří Sluneční soustavy pojmenované Rheasilvia (s výškou cca $23 \mathrm{~km}$ ), které vystupuje v impaktní pánvi o průměru $505 \mathrm{~km}$ - jedná se zřejmě zatím o nejrozlehlejší kráter Sluneční soustavy. Vysvětlení původu těchto výrazných struktur asteroidu se zatím přiklání spíše k impaktní aktivitě než k projevům vulkanismu, který zatím nebyl během výzkumů mise Dawn detekován (obr. 2).

Termální historií (metoda ${ }^{39} \mathrm{Ar}-{ }^{40} \mathrm{Ar}$ ) asteroidu Vesta se nově zabývali Bogard - Garrison (2003). Těleso bylo zřejmě zformováno před více než $4,56 \mathrm{Ga}$. Následně rozpad radionuklidů způsobil rozsáhlé tavení (vznik jádra a povrchu z bazaltové lávy). Kumulátové eukrity naznačují intenzivnější působení teplot než bazaltické eukrity, což znamená, že vznikaly ve větších hloubkách. Mohutný impakt před zhruba 4,5 Ga mohl vytvořit kráter a vyvrhnout na povrch materiál kumulátových a nebrekciovaných bazaltických eukritů. Křemenné žilky objevené v eukritu Serra de Magé vznikly patrně z vodních roztoků, což může znamenat kontaminaci Vesty vodní složkou díky impaktům komet. Nelze vyloučit možnost existence vodního ledu pod povrchem tělesa či na dnech hlubokých kráterů, o čemž svědčí i měření povrchové teploty Vesty během současné mise Dawn.

\section{Metodika}

Pro srovnávací výzkum byly získány a studovány následující vzorky pouštních nálezů eukritů: Northwest Africa (NWA) 5235 - nalezen v roce $2007 \mathrm{v}$ poušti severozápadní Afriky o celkové váze pouhých $70 \mathrm{~g}$. Eukrit Hammadah al Hamra (HaH) 286 byl nalezen v libyjské poušti - v oblasti Jabal al Gharb, nalezený kus vážil $612 \mathrm{~g}$. Pro analýzy bylo dostupné velmi omezené množství materiálu. Zhotovené výbrusy byly analyzovány elektronovou mikrosondou Cameca SX 100 na společném pracovišti ČGS a Ústavu geologických věd PřF MU v Brně. Měření probíhalo ve vlnově disperzním módu za následujících podmínek: urychlovací napětí $15 \mathrm{kV}$, průměr elektronového svazku $5 \mu \mathrm{m}$, proud $10 \mathrm{nA}$, načítací čas 20 sekund, operátor R. Škoda. Jako standardy byly užity syntetické fáze či dobře definované minerály. Data byla korigována metodou PAP (Pouchou and Pichoir 1985). Pro zjištění celkového chemismu byly použity částečné výsledky neutronové aktivační analýzy INAA. Upravené vzorky byly ozářeny $\mathrm{v}$ reaktoru LVR-15 Ústavu jaderného výzkumu v Řeži za použití 3 modů a tří syntetických multiprvkových standardů (MES), analýzy provedl Z. Řanda.

Petrografická a geochemická charakteristika vzorků eukritů NWA 5235 a HaH 286

\section{NWA 5235}

Jedná se o poměrně čerstvý vzorek meteoritu šedé barvy s dvěma makroskopicky viditelnými litologiemi - tmavší část s ofitickou strukturou a světlejší, hrubozrnná část, jak je patrné z obr. 3. Vzhledem k omezenému množství vzorku však nelze objasnit, zda může být NWA 5235 monomiktní či polymiktní brekcie. Minerální složení v obou částech je obdobné a sestává z plagioklasu $\left(\mathrm{An}_{81-91}\right)$ 


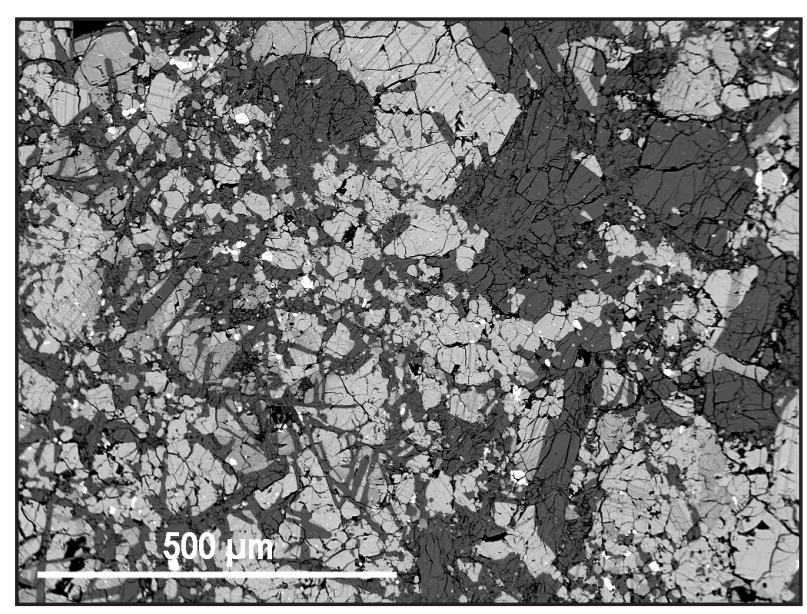

Obr. 3: BSE foto vzorku NWA 5235 - dva typy litologií, v levé části patrná ofitická struktura.

Fig. 3: Backscattered electron images of NWA 4536 - two lithologies - left part of the image shows ophitic texture.

a pyroxenů, bez př́tomnosti olivínu, s akcesoriemi ilmenitem (obsahujícím $1 \mathrm{hm} . \% \mathrm{MnO}$ ), chromitem a troilitem. Zrna minerálů jsou tektonicky deformována jako důsledek impaktové aktivity. Složení nízce vápenatého pyroxenu se pohybuje v rozmezí $\mathrm{Wo}_{1-4} \mathrm{En}_{33-34} \mathrm{Fs}_{62-65}$ a Ca-pyroxenu $\mathrm{Wo}_{34-43} \mathrm{En}_{28-30} \mathrm{Fs}_{28-36}$. Téměř každé zrno nízce-vápenatého pyroxenu má odmíšené lamely augitického složení o šířce 2-5 $\mu \mathrm{m}$, zonálnost pozorována nebyla.

\section{HaH 286}

U tohoto vzorku byla zaznamenána pouze jedna litologie a to s ofitickou texturou, známky brekciace pozorovány nebyly. $\mathrm{V}$ tomto př́padě se zřejmě jedná o vzácný nebrekciovaný eukritový bazalt (obr. 4). Většina analyzovaných pyroxenů jsou pigeonity $\mathrm{Wo}_{7} \mathrm{En}_{35} \mathrm{Fs}_{58}$. Augit $\left(\mathrm{Wo}_{42}\right.$ $\mathrm{En}_{29} \mathrm{Fs}_{29}$ ) se vyskytuje zřídka. Nízce-vápenatý pyroxen $\mathrm{Wo}_{3}$ $\mathrm{En}_{36} \mathrm{Fs}_{61}$ má tenké odmíšené augitové lamely (cca $\left.1 \mu \mathrm{m}\right)$ a vyskytují se v nich i orientované odmíšeniny Cr-spinelu. Plagioklasy $\left(\mathrm{An}_{79-91}\right)$ jsou prorůstány jehličkami pyroxenů. Z akcesorií byl zaznamenán ilmenit $(0,8 \mathrm{hm}$. \% MnO), chromit, troilit, ojediněle fáze $\mathrm{SiO}_{2}$. Některá zrna plagio-

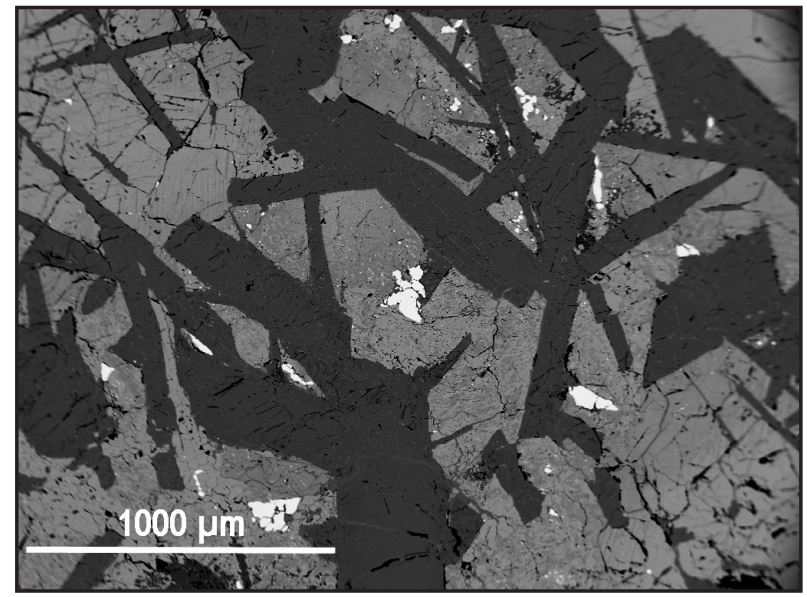

Obr. 4: BSE foto vzorku HaH 286 - ofitická struktura, lišty plagioklasu, pigeonit, ilmenit.

Fig. 4: Backscattered electron images of $\mathrm{HaH} 286$ - ophitic texture - lathes of plagioclase with pigeonite and ilmenite. klasu jsou lemována kalcitovými žilami, jde o sekundární výplň puklin jako projev pozemského zvětrávání.

Na základě analýz pyroxenů spadají NWA 5235 a HaH 286 svým složením mezi bazaltové eukrity. Původním pyroxenem je pigeonit s primární zonálností uchovanou $\mathrm{v}$ závislosti na intenzitě metamorfózy. Ve většině př́padů však působí Fe/Mn ekvilibrace a odmíšení augitu. Ani studované vzorky nejsou výjimkou. V eukritu NWA 5235 není zonálnost dochována, může se jednat o 5-6 metamorfní stupeň dle škály stanovené Takedou - Grahamem (1991) a za působení teplot $\sim 1000{ }^{\circ} \mathrm{C}$ tak mohlo dojít k homogenizaci $\mathrm{Ca}-\mathrm{Mg} \mathrm{v}$ původních zonálním pyroxenech (Yamaguchi et al. 1996).

Celkový chemismus obou vzorků odpovídá hlavní skupině eukritů typu Juvinas, což ukazují výsledky analýz $\mathrm{v}$ tab. 2. Poměr celkového Fe/Mn (=31-32) u NWA 5235 a $\mathrm{HaH} 286$ spolu s poměrem Fe/Mn v pyroxenech (=29-36) je v rozmezí typickém pro HED meteority (Hill et al. 1991). Index hořečnatosti mg\# $(=100 \times \mathrm{Mg} /(\mathrm{Mg}+\mathrm{Fe})$ u NWA 5235 je cca 40,4 s poměrem $\mathrm{FeO}_{\text {total }} / \mathrm{MgO}(=2,6)$. Vzorek HaH 286 má \#mg $(=42,3)$ a poměr celkového $\mathrm{FeO}_{\text {total }} / \mathrm{MgO}(=2,4)$, což značí o něco vyšší hořečnatost, i když stále spadá do pole řádných nekumulátových eukritů, podobných hlavní eukritové skupině. Obsahy $\mathrm{TiO}_{2}$ jsou nízké $\left(0,7 \mathrm{hm}\right.$. \%), stejně tak i obsahy $\mathrm{K}_{2} \mathrm{O}$ $(0,04-0,06 \mathrm{hm} . \%)$, což vylučuje př́buznost s eukrity typu Stannern. Eukrity s vyšším obsahem $\mathrm{TiO}_{2}$ a nižší mg\# patří k dalšímu eukritovému typu Nuevo Laredo, což ale také není případ NWA 5235 a HaH 286 (obr. 5). Oba vzorky mají podobné složení a podle obsahů $\mathrm{CaO}, \mathrm{Al}_{2} \mathrm{O}_{3}$, $\mathrm{TiO}_{2}, \mathrm{Cr}_{2} \mathrm{O}_{3}$ i mg\# náleží do hlavní eukritové skupiny typu Juvinas. Ani jeden ze studovaných eukritů nelze dobře korelovat se Stannern nebo Nuevo Laredo trendem, s hlavní skupinou je více př́buzný NWA 5235 než HaH 286. Vzhledem k omezenému množství materiálu pro výzkum je obtížné určit, zda se jedná o monomiktní či oligomiktní brekcie nebo vzácné nebrekciované bazalty.

\section{Závěr}

Meteorit Stonařov je vápníkem bohatý nekumulátní monomiktní brekciovitý obecný eukrit a představuje typový meteorit - Stannern typ (Ikeda - Takeda 1985, Takeda 1997) s velmi slabým částečným natavením hmoty.

\begin{tabular}{|l|c|c|c|c|c|}
\hline $\mathbf{h m} . \%$ & $\begin{array}{c}\text { NWA } \\
\mathbf{5 2 3 5}\end{array}$ & HaH 286 & Juvinas* $^{*}$ & Stannern $^{*}$ & $\begin{array}{c}\text { Nuevo } \\
\text { Laredo }\end{array}$ \\
\hline $\mathbf{M g O}$ & 6,9 & 7,1 & 7 & 7 & 5,5 \\
\hline $\mathrm{Al}_{2} \mathbf{O}_{3}$ & 12,5 & 12,8 & 13,1 & 12,2 & 12 \\
\hline $\mathrm{SiO}_{2}$ & 49,6 & 48,6 & 49,1 & 49,2 & 49,5 \\
\hline $\mathbf{K}_{2} \mathbf{O}$ & 0,1 & 0 & 0 & 0,1 & 0,1 \\
\hline $\mathbf{C a O}$ & 9,5 & 10,8 & 10,7 & 10,6 & 10,3 \\
\hline $\mathrm{TiO}_{2}$ & 0,7 & 0,7 & 0,6 & 1 & 0,9 \\
\hline $\mathbf{M n O}$ & 0,6 & 0,6 & 0,5 & 0,5 & 0,6 \\
\hline $\mathbf{F e O}$ & 18 & 17,3 & 17,9 & 18,1 & 19,4 \\
\hline
\end{tabular}

Tab. 2. Chemismus studovaných pouštních nálezů eukritů ve srovnání s typovými členy podskupin eukritů.

Tab. 2. Bulk composition of studied desert find eucrites in comparison to eucrite trend representatives. 


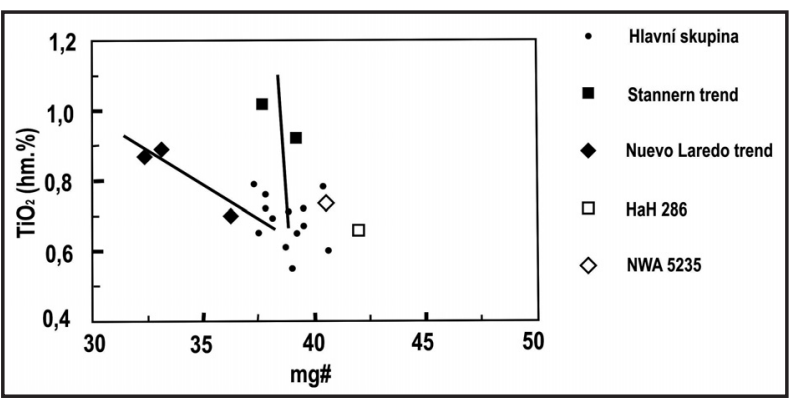

Obr. 5: Diagram $\mathrm{TiO}_{2}$ versus mg\# pro bazaltické eukrity (upraveno dle Papike et al. 1998).

Fig. 5: $\mathrm{TiO}_{2}$ versus mg\# diagram for basaltic eucrites (after Papike et al. 1998).

Studované vzorky NWA 5235 a HaH 286 jsou od meteoritu Stannern odlišné, spadají do hlavní eukritové skupiny podobné typu Juvinas, které vznikly jako bazalty zřejmě parciálním tavením materiálu mateřského tělesa eukritů, pravděpodobně asteroidu Vesta. Eukrit NWA 5235 jako monomiktní či oligomiktní brekcie reprezentuje nejčastější eukritové nálezy. HaH 286 může patřit mezi vzácné, nebrekciované eukrity, jejichž složení napovídá, že vznikaly v hlubší části kůry mateřského asteroidu. Studium eukritových bazaltů nám dává možnost zatím nepř́mo poznat procesy vývoje menších těles Sluneční soustavy - asteroidů. V př́padě planetky Vesta tyto procesy, tj. zahřátí, roztavení, frakcionace, extruze a solidifikace bazaltové kưry, proběhly v prvních 10 milionech let historie naší Sluneční soustavy (např. Nyquist et al. 2001). Vesta a diferencované asteroidy podobného typu mohou představovat trpasličí terestrické planety, popř. jejich embrya, která hrála důležitou roli při formaci větších terestických planet (např. Carlson - Lungmair 2000). V př́padě, že bude mise Dawn úspěšně dokončena, bude možné s jistotou potvrdit, že asteroid Vesta je mateřským tělesem eukritů, potažmo HED meteoritů. Zároveň by měly být přesněji zjištěny podmínky a procesy i role vodní složky pro vývoj našeho planetárního systému a míra jeho evoluce. Moravský meteorit Stannern díky svému unikátnímu složení mezi eukrity výrazně napomohl k pochopení magmatických procesů mimozemských těles. Zatím však není s jistotou prokázáno, že tento meteorit má totožný původ jako meteority z asteroidu Vesta a tak nelze vyloučit jeho původ z jiného tělesa či asteroidu. I proto moravský meteorit Stannern nalezený nadále zůstává jedním z nejzajímavějších meteoritů na světě.

\section{Poděkování}

Poděkování patři RNDr. Marcele Bukovanské, CSc., dále doc. Ing. Zdeňku Řandovi, DrSc., za provedení analýz INAA, Mgr. Radku Škodovi, Ph.D., za vyhotovení WDX analýz a panu Jiř́mu Povolnému za zhotovení výbrusů. Laboratorní práce byly finančně podpořeny grantem Royal Astronomical Society, UK.

\section{Literatura}

Barrat, J. A. - Yamaguchi, A. - Greenwood, R. C. - Bohn, M. - Cotten, J. - Benoit, M. - Franchi, I. A. (2007): The Stannern trend eucrites: Contamination of main group eucritic magmas by crustal partial melts. - Geochim. Cosmochim. Acta, 71, 4118.

Birck, J. L. - Allegre, C. J. (1978): Chronology and chemical history of the parent body of basaltic achondrites studied by the 87Rb-87Sr Method. - Earth Planet. Sci. Lett, 39, 37-51.

Bogard, D. D. - Garrison, D. H. (2003): ${ }^{39} \mathrm{Ar}-{ }^{40} \mathrm{Ar}$ ages of eucrites and thermal history of asteroid (4)Vesta. - Meteoritics and Planet. Sci. 38, 5

Bukovanská, M. (2008): Meteorit Stonařov - Stannern: Historie pádu, petrologie a stáŕí meteoritu. - Stonařovské meteority 1808-2008. Muzeum Vysočiny, 59-65. Jihlava. 
Bukovanská, M. - Ireland, T. R. (1992): Dating and Zr/Hf ratio of zircons and baddeleyites in eucrites. - Abstract 24 $4^{\text {th }}$ An. Meet., Munich. - Bulletin of the American Astronomical Society. 24, 941.

Bukovanská, M. - Němec, I. - Šolc, M. (1998): Infrared microscopic method and possible correlations of FTIR spectra of the meteorites. - Abstract 61 ${ }^{\text {th }}$ An. Meet. Meteor. Soc. - Meteoritics and Planet. Sci. 33, 25-26.

Carlson, R. W. - Lungmair, G. W. (2000): Timescales of planetesimal formation and differentiation based on extinct and extant radioisotopes. - In: Canup, R. M. - Righter, K. (eds): Origin of the Earth and Moon, Univ. Arizona, 25-44.

Clayton, R. N. - Mayeda, T. K. (1996): Oxygen isotopes studies of achondrites. - Geochim. Cosmochim. Acta 60, $1999-2017$.

Consolmagno, G. J. - Drake, M. J. (1977): Composition and evolution of the eucrite parent body: Evidence from rare elements. Geochimica et Cosmochimica Acta, 41, $1271-1282$.

Drake, M. J. (1979): Geochemical evolution of the eucrite parent body: Possible nature and evolution of asteroide 4Vesta. - In: Gehrels, A. M. J. (ed.): Asteroids, Univ. Arizona Press, Tuscon.

Engelhardt, W. von (1963): Der Eukrite von Stannern. - Beitrage zur Mineral und Petrography, 9, 65-94.

Gardner, K. G. - Mittlefehldt D. V. (2004): Petrology of New Stannern-trend eucrites and eucrite genesis. - Lunar and Planetary Science XXXV, abst. 1349.

Gray, C. M. - Papanastassiou, D. A. - Wasserburg, G. J. (1973): The identification of early condensates from the solar nebula. Icarus 20, 213-239.

Hill, D. H. - Boynton, W. V. - Haag, R. A. (1991): A lunar meteorite outside the Antarctic. - Science 352, 614-617.

Ikeda, Y. - Takeda, H. (1985): A model for origin of basaltic achondrites based on the YAMATO - 7308 howardite. - Lunar and Planetary Science Conference, 15, 649-663.

Ireland, T. - Bukovanská, M. (1992): Zircons from the Stannern eucrite. - Abstract 55 ${ }^{\text {th }}$ Ann. Meet. Met. Soc. Copenhagen. Meteoritics 27, 3, 237.

Kitts, K. - Lodders, K. (1998): Survey and evaluation of eucrite bulk composition. - Meteoritics and Planet. Sci., 33, 197-213.

Kohlík, J. (1970): Noviny dávných staletí. - Vydavatelství a nakladatelství Novinář, 108-109, Praha.

Köblitz, J. (1994): Metbase. - Elektronická databáze.

Larson, H. P. - Fink, U. (1975): Infrared spectral observation of asteroid 4Vesta. - Icarus 36, 420-427.

Mason, B. (1962): Meteorites. - John Wiley and Sons, 274, New York.

McCord, T. B. - Adams, J. B. - Johnson, T. V. (1970): Asteroid Vesta: Spectral reflectivity and compositial implications. - Science $168,1445-1447$

Melosh, H. J. (1984): Impact ejection, spallation, and the origin of meteorites. - Icarus 59, 234-260.

Newsom, H. E. - Drake, M. J. (1982): The metal content of the eucrite parent body. Constraints from the partitioning behavior of tungsten. - Geochimica et Cosmochimica Acta, 46, 2 483-2 489.

Nyquist, L. E. - Reese, Y. - Wiesmann, H. - Shih, C. Y. - Takeda, H. (2001): Dating eucrite formation and metamorphism. - Antarctic meteorites, XXVI, 113-115. National Institute of Polar Research, Tokyo.

Ondra, L. (2008): Osudy stonařovských meteoritů. - Stonařovské meteority 1808-2008. Muzeum Vysočiny, 115-127.

Papike, J. J. - Graham, R. - Shearer, C. K. (1998): Lunar samples. - In: Papike, J. J. - Ribbe, P. H. (eds): Planetary Materials, The Mineralogical Society of America, Washington 4-171.

Peltán, L. (2008): Dobové ohlasy pádu meteoritů ve Stonařově a okolí 22. května 1808. - Stonařovské meteority $1808-2008$. Muzeum Vysočiny, 97-114.

Pouchou, J. L. - Pichoir, F. (1985): PAP (Z) procedure for improved quantitative microanalysis. - Microbeam Analysis, 104-106.

Rose, G. (1863): Systematisches Verzeichnis der Meteoriten in den Meteoriten in den mineralogischen Museum der Universität zu Berlin. - Annalen der Physik 118, 419-423.

Schreibers, C. von (1808): Meteoritenfall zu Stannern. - Gilbert's Annalen Der Physik, 29, 225.

Schreibers, C. von (1809): Beschreibung der mährischen Meteorsteine nach ihrem Ausseren vorzüglich der Ringe etc. - Gilbert's Annalen Der Physik, 31, 23-71.

Stolper, E. (1977): Experimental petrology of eucrite meteorites. - Geochimica et Cosmochimica Acta, 41, 587-611.

Šimčíková, M. (2008): Achondrity HED. - Stonařovské meteority 1808-2008. Muzeum Vysočiny, 51-57.

Takeda, H. - Graham, A. L. (1991): Degree of equilibration of eucritic pyroxenes and thermal metamorphism of the earliest planetary crust. - Meteoritics 26, 129-134.

Takeda, H. (1997): Mineralogical records of early planetary processes on the howardite, eucrite, diogenite parent body with reference to Vesta. - Meteoritics and Planet. Sci., 32, 841-853.

Thomas, P. C. - Binzel, R. P. - Gaffey, M. J. - Storrs, A. D. - Wells, E. N. - Zellner, B. H. (1997): Impact excavation on asteroid 4Vesta: Hubble Space Telescope results. - Science 277, 1 492-1 495.

Tschermak, G. (1872): Die meteoriten von Stannern, Konstantinopol, Shergotty and Gopalpur. - Tschermak's min. - petr. Mitth., 2, 85-87.

Yamaguchi, A. - Taylor, G. J. - Keil, K. (1996): Global crustal metamorphism of the eucrite parent body. - Icarus 124, 97-112.

Yamaguchi, A. - Barrat, J. A. - Greenwood, R. C. - Shirai, N. C. - Okamoto, C. T. - Setoyanagi, T. - Ebihara, M. - Franchi, I. A. - Bohn, M. (2009): Crustal partial melting on Vesta: Evidence from highly metamorphosed eucrites. - Geochimica et Cosmochimica Acta, 73, 23, 7 162-7 182. 